\title{
EFEKTIVITAS PENDEKATAN METAKOGNISI TERHADAP PENALARAN MATEMATIS PADA MATAKULIAH GEOMETRI TRANSFORMASI
}

\author{
Oleh: \\ Muchamad Subali Noto \\ Pendidikan Matematika FKIP Universitas Swadaya Gunung Jati Cirebon \\ Balimath61@gmail.com
}

\begin{abstract}
ABSTRAK
Penguasaan materi geometri transformasi yang masih rendah, berdampak pada hasil belajar yang belum memuaskan. Beberapa hal juga disebabkan karena mahasiswa kurang memahami bagaimana cara menyelesaikan soal-soal pembuktian dalam geometri tranformasi, oleh sebab itu mahasiswa harus mengetahui cara belajar yang tepat, mulai dari merencanakan sampai dengan menyelesaikan soal pembuktian. Oleh sebab itu mahasiswa harus bisa berpikir bagaimana cara berpikir, sehingga kemampuan penalaran matematis yang baik sangatlah diperlukan. Salah satu pendekatan pembelajaran yang menyadarkan cara berpikir mahasiswa adalah pendekatan metakognisi. Populasi dalam penelitian ini adalah mahasiswa tingkat dua Unswagati, dengan teknik cluster sampling terpilih kelas kontrol dan kelas eksperimen. Data diperoleh melalui tes penalaran matematis dan lembar pengamatan. Data diolah secara deskriptif, uji banding one sample $t$ test dan analisis regresi. Hasil menunjukkan bahwa pembelajaran dengan pendekatan metakognitif efektif terhadap penalaran matematis mahasiswa, beberapa indikator terpenuhi, yaitu (1) Penalaran matematis mahasiswa mencapai kriteria ketuntasan klasikal yaitu 73.33 lebih besar dari KKM sebesar 65, (2) Keaktifan mahasiswa pada pembelajaran dengan pendekatan metakognisi berpengaruh positif terhadap penalaran matematis mahasiswa sebesar 39,60\%, (3) Rata-rata penalaran matematis mahasiswa pada kelas eksperimen (rata-rata 73.33) lebih baik daripada kelas kontrol (rata-rata 40,38).
\end{abstract}

Kata Kunci : Efektivitas, Metakognisi, Penalaran Matematis dan Geometri Transformasi

\begin{abstract}
Mastery of geometry transformation is still low, have an impact on learning outcomes are not satisfactory. Some of it is also due to students not understand how to solve the problems of proof in geometry transformation, therefore, students should know the proper way of learning, ranging from planning to solve problems of proof. Therefore, students should be able to think how to think, so good mathematical reasoning ability is required. One approach to learning that students are aware of the way of thinking metacognitive approach. The population in this study was a sophomore Unswagati, selected by cluster sampling technique is one control and one experiment class. Data were obtained through tests of mathematical reasoning and observation sheet. Data processed by descriptive, comparative test sample ttest and regression analysis. The results showed that the effective learning of metacognitive
\end{abstract}


approach to mathematical reasoning students, some indicators are met, namely (1) the mathematical reasoning students achieve classical completeness 73.33 are greater than KKM at 65 , (2) the student's activeness on metacognitive approach to learning with a positive effect on mathematical reasoning students by $39.60 \%$, (3) average of mathematical reasoning student in a class experiments (average 73.33) is better than the control class (average 40.38).

Keywords: Effectiveness, Metacognition, Mathematical Reasoning and Geometry Transformation

\section{PENDAHULUAN}

Hvidsten (2005) menyatakan bahwa geometri merupakan satu bagian yang paling kaya dalam eksplorasi matematika. Aspek-aspek visual pada geometri menjadikan ekslporasi dan eksperimentasi alami dan intuitif. Di sisi lain, abtraksi-abstraksi yang dikembangkan untuk menjelaskan pola dan hubungan geometri menjadikan geometri sebagai subyek yang sangat penting dan dapat diterapkan pada bermacammacam situasi.

Geometri mempunyai posisi yang strategis untuk menumbuhkembangkan kemampuan bernalar mahasiswa dan dapat dipandang sebagai latihan untuk menata nalar atau wawasan keruangan mahasiswa. Namun keadaan di lapangan menunjukkan bahwa penguasan materi geometri oleh mahasiswa masih lemah terutama geometri transformasi, ini ditunjukkan dari data hasil UTS mahasiswa yang nilainya kurang dari KKM (65). Salah satu kelemahan penguasaan materi geometri oleh mahasiswa adalah karena sukar memahami konsep transformasi sehingga kesulitan dalam membuktikan beberapa sifat dalam transformasi, oleh sebab itu mahasiswa harus mengetahui cara belajar yang tepat, mulai dari merencanakan sampai dengan menyelesaikan soal pembuktian. Oleh sebab itu mahasiswa harus bisa berpikir bagaimana cara berpikir, sehingga kemampuan penalaran matematis yang baik sangatlah diperlukan.

Gambaran kemampuan penguasaan materi geometri transformasi yang masih rendah berdampak pada hasil belajar yang belum memuaskan. Kenyataan tersebut memerlukan perhatian dari pengajar untuk menggunakan pendekatan pembelajaran yang menyadarkan cara berpikir mahasiswa serta mampu meningkatkan pemahaman konsep dan penalaran mahasiswa terhadap materi geometri transformasi. Dengan hal tersebut perlu adanya suatu upaya meningkatkan penalaran matematis mahasiswa, salah satunya yaitu pendekatan metakognisi.

Berdasarkan uraian diatas penulis, tujuan dari penelitian ini adalah untuk mengetahui efektivitas pendekatan metakognisi terhadap matakuliah geometri transformasi. 


\section{METODE PENELITIAN}

Penelitian ini merupakan penelitian eksperimen dengan kelas eksperimen menggunakan pendekatan metakognisi dan kelas kontrol dengan pembelajaran ekspositori. Subjek penelitian adalah mahasiswa tingkat dua Universitas Swadaya Gunung Jati. Pemilihan sampel menggunakan teknik cluster sampling. Menurut Ruseffendi (2010: 95), teknik sampling ini memberikan peluang yang sama bagi setiap kelompok dengan karaktieritik yang sama dari populasi. Desain penelitian yang digunakan adalah Posttest-Only Control Design (Sugiono, 2009: 112) sebagai berikut.

$$
\begin{array}{lll|}
\hline \mathrm{R}_{\mathrm{E}}: & \mathrm{X} & \mathrm{O} \\
\mathrm{R}_{\mathrm{K}}: & & \mathrm{O} \\
\hline
\end{array}
$$

\section{Gambar 2.1 Desain Penelitian}

Keterangan :

$\mathrm{R}_{\mathrm{E}}=$ kelompok eksperimen

$\mathrm{R}_{\mathrm{K}}=$ kelompok kontrol

$\mathrm{X}=$ pembelajaran dengan pendekatan metakognisi

$\mathrm{O}=$ tes penalaran matematis

Dalam desain ini terdapat dua kelas, satu sebagai kelas yang diberi perlakuan yaitu kelas eksperimen dan yang lain adalah kelas yang tidak diberi perlakuan yaitu kelas kontrol. Kemudian dua kelas tersebut diberi tes penalaran matematis yang sama. Dan alur penelitian adalah sebagai berikut.

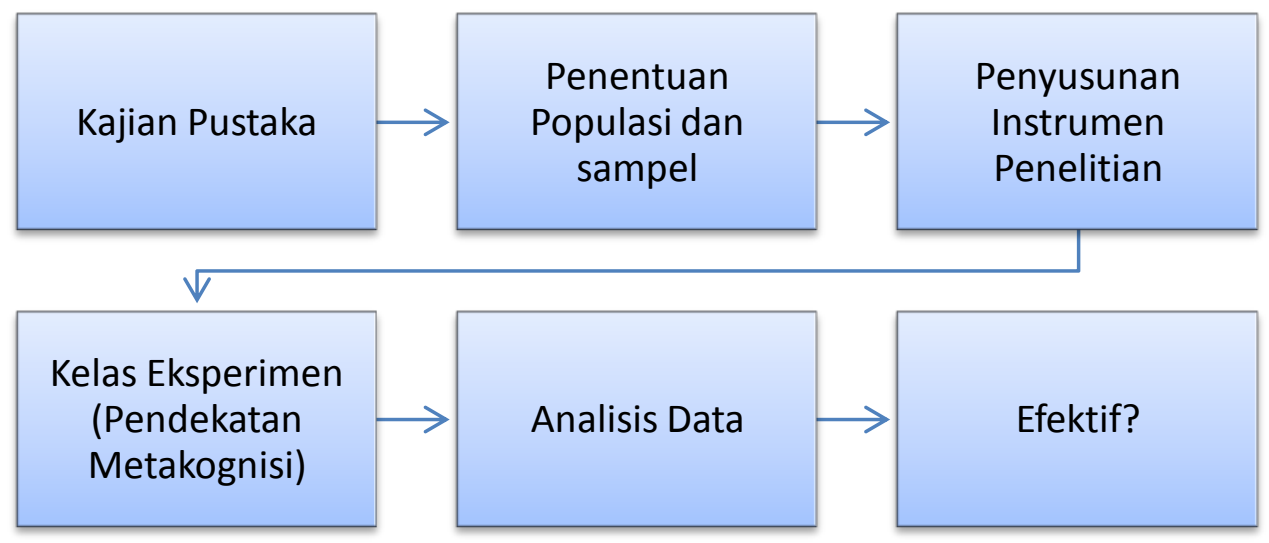

Gambar 2.2 Alur Penelitian 
Teknik pengolahan data pada penelitian ini adalah sebagai berikut.

Tabel 2.1

Teknik Pengolahan Data

\begin{tabular}{lll}
\hline No & Analisis dan Hipotesis & Un \\
\hline 1 & Ketuntasan Klasikal & \\
& & \\
& Hipotesis : & \\
& $\mathrm{H}_{0}: \mu<65$ \\
& $\mathrm{H}_{1}: \mu \geq 65$
\end{tabular}

2 Uji Pengaruh

Hipotesis:

$\mathrm{H}_{0}: b=0$

$\mathrm{H}_{1}: b \neq 0$

3 Perbedaan nilai rata-rata penalaran matematis mahasiswa kelas eksperimen dengan kelas kontrol

Hipotesis:

$\mathrm{H}_{0}: \mu_{1}=\mu_{2}$

$\mathrm{H}_{1}: \mu_{1} \neq \mu_{2}$

Uji Statistik

Uji rata-rata satu pihak, menggunakan one sample t-test dengan SPSS

Uji Regresi dengan SPSS

Uji Independent sampel t-tes dengan SPSS di mana $\alpha=5 \%$

\section{Interpretasi \\ Nilai signifikan dibandingkan dengan alpha sebesar $0.05=5 \%$ dengan kriteria $\mathrm{H}_{0}$ ditolak jika sig. < $5 \%$.}
Nilai signifikan dibandingkan dengan alpha sebesar $0.05=5 \%$ dengan kriteria $\mathrm{H}_{0}$ ditolak jika sig. < $5 \%$.

Nilai signifikan dibandingkan dengan alpha sebesar $0.05=5 \%$ dengan kriteria $\mathrm{H}_{0}$ ditolak jika sig. < $5 \%$.

(Sukestiyano, 2010)

\section{HASIL DAN PEMBAHASAN}

\section{Uji Ketuntasan}

Berdasarkan nilai hasil tes penalaran matematis mahasiswa pada kelas eksperimen, dilakukan uji ketuntasan klasikal dengan menggunakan uji rata-rata satu sampel. Hipotesis statistiknya seperti berikut ini.

Hipotesis $\mathrm{H}_{0}: \mu<65$ (rata-rata nilai tes penalaran matematis kurang dari 65 )

$\mathrm{H}_{1}: \mu \geq 65$ (rata-rata nilai tes penalaran matematis lebih dari atau sama dengan 65) 
Dari data tersebut selanjutnya dilakukan analisa data uji ketuntasan klasikal menggunakan One Sample Test dan diperoleh hasil seperti yang dapat dilihat pada Tabel 3.1.

Tabel 3.1

Uji Ketuntasan Kelas Uji coba Perangkat

\begin{tabular}{|c|c|c|c|c|c|c|}
\hline & \multicolumn{9}{|c|}{ Test Value =65 } \\
\cline { 5 - 7 } & $\mathrm{t}$ & $\mathrm{df}$ & $\begin{array}{c}\text { Sig. } \\
(2 \text {-tailed })\end{array}$ & $\begin{array}{c}\text { Mean } \\
\text { Difference }\end{array}$ & $\begin{array}{c}\text { 95\% Confidence Interval of the } \\
\text { Difference }\end{array}$ \\
\cline { 5 - 7 } & & & $\mathbf{0 1 7}$ & 8.524 & 1.68 & 15.37 \\
\hline $\begin{array}{c}\text { Penalaran } \\
\text { Matematis }\end{array}$ & 2.599 & 20 & $\mathbf{. 0 1 7}$ & Lower & Upper \\
\hline
\end{tabular}

Karena nilai sig $=0,017=1,7 \%<5 \%$, maka $\mathrm{H}_{0}$ ditolak. Artinya rata-rata nilai tes penalaran matematis pada kelas eksperimen lebih dari atau sama dengan 65 . Selanjutnya untuk mengetahui bahwa nilai rata-rata ketuntasan kelas eksperimen lebih dari 65 dilihat dari Tabel 3.2 di bawah ini.

Tabel 3.2

Rata-rata nilai Tes Penalaran Matematis

\begin{tabular}{|c|c|c|c|c|}
\hline & $\mathrm{N}$ & Mean & $\begin{array}{c}\text { Std. } \\
\text { Deviation }\end{array}$ & Std. Error Mean \\
\hline Tes_Prestasi_Belajar & 21 & $\mathbf{7 3 . 5 2}$ & 15.032 & 3.280 \\
\hline
\end{tabular}

Diperoleh rata-rata untuk penalaran matematis kelas eksperimen sebesar 73,52. Maka nilai rata-rata ketuntasan belajar kelas eksperimen lebih dari 65 .

\section{Uji Pengaruh}

Untuk uji pengaruh menggunakan uji regresi sederhana, sebagai variabel independent adalah aktivitas mahasiswa dalam pendekatan metakognisi (X) dan variabel dependent adalah penalaran matematis mahasiswa. Dengan hipotesis statistik sebagai berikut.

$\mathrm{H}_{0}: b=0$ (persamaan regresi tidak linear yang berarti tidak terdapat pengaruh aktivitas mahasiswa dalam pendekatan metakognisi terhadap penalaran matematis)

$\mathrm{H}_{1}: b \neq 0$ (persamaan regresi linear yang berarti bahwa terdapat pengaruh aktivitas mahasiswa dalam pendekatan metakognisi terhadap penalaran matematis)

Dengan persamaan regresi adalah $\hat{Y}=a+b X$. 
Hasil menunjukkan bahwa terdapat hubungan antara aktivitas mahasiswa dalam pendekatan metakognisi dengan penalaran matematis mahasiswa. Besar hubungan dapat dilihat dari besarnya nilai $R$ yaitu $63 \%$. Hasil juga menunjukkan bahwa pada tabel 3.3, nilai sig $0,002<5 \%$ maka $\mathrm{H}_{0}$ ditolak sehingga persamaan regresi linear, artinya terdapat pengaruh aktivitas mahasiswa dalam pendekatan metakognisi terhadap penalaran matematis.

Tabel 3.3

Uji Signifikansi Pengaruh Aktivitas terhadap Penalaran Matematis

\begin{tabular}{|l|c|c|c|c|c|}
\hline \multicolumn{1}{|c|}{ Model } & Sum of Squares & Df & Mean Square & F & Sig. \\
\hline Regression & 1791.836 & 1 & 1791.836 & 12.483 & $\mathbf{. 0 0 2}$ \\
Residual & 2727.402 & 19 & 143.547 & & \\
Total & 4519.238 & 20 & & & \\
\hline
\end{tabular}

Selanjutnya dari Tabel 3.4 dapat diperoleh bentuk persamaan regresinya adalah $\hat{Y}=36,792+0,591 X_{1}$. Ini menunjukkan bahwa penambahan satu satuan aktivitas mahasiswa akan memberikan kontribusi sebesar 0,591 pada penalaran matematis mahasiswa.

Tabel 3.4

Koefisien Persamaan Regresi

\begin{tabular}{|c|c|c|c|c|c|}
\hline \multirow[b]{2}{*}{ Model } & \multicolumn{2}{|c|}{$\begin{array}{c}\text { Unstandardized } \\
\text { Coefficients }\end{array}$} & \multirow{2}{*}{\begin{tabular}{|c|}
$\begin{array}{c}\text { Standardized } \\
\text { Coefficients }\end{array}$ \\
Beta \\
\end{tabular}} & \multirow[b]{2}{*}{$\mathrm{T}$} & \multirow[b]{2}{*}{ Sig. } \\
\hline & B & Std. Error & & & \\
\hline $1 \quad$ (Constant) & 36.792 & 10.720 & & 3.432 & .003 \\
\hline Keaktifan & .591 & .167 & .630 & 3.533 & .002 \\
\hline
\end{tabular}

$\mathrm{R}$ quare pada Tabel 3.5 sebesar 0,3960 = 39,60\% menunjukkan kecocokan data yang baik dengan model persamaan regresi yang diperoleh atau dapat diartikan bahwa penalaran matematis dapat diterangkan sebesar 39,60\% oleh aktivitas mahasiswa dalam pendekatan metakognisi, dengan kata lain terdapat pengaruh aktivitas mahasiswa sebesar $39,6 \%$ terhadap penalaran matematis pada persamaan regresi yang diperoleh.

\section{Tabel 3.5}

R Square

\begin{tabular}{|l|r|r|c|c|}
\hline Model & \multicolumn{1}{|c|}{$\mathrm{R}$} & R Square & $\begin{array}{c}\text { Adjusted R } \\
\text { Square }\end{array}$ & $\begin{array}{c}\text { Std. Error of the } \\
\text { Estimate }\end{array}$ \\
\hline $\mathbf{1}$ & $\mathbf{. 6 3 0}$ & $\mathbf{. 3 9 6}$ & .365 & 11.981 \\
\hline
\end{tabular}




\section{Uji Banding}

Uji banding dimaksudkan untuk mengetahui perbedaan rata-rata penalaran matematis yang diperoleh melalui data tes penalaran matematis (TPM) dari kelas eksperimen dan kelas kontrol. Uji banding menggunakan independent sample t test dengan langkah yang pertama adalah uji kesamaan varian, hipotesis yang digunakan seperti berikut ini.

$\mathrm{H}_{0}: \sigma_{1}{ }^{2}=\sigma_{2}{ }^{2}$ (tidak terdapat perbedaan varians penalaran matematis antara kelas eksperimen dan kelas kontrol yang berarti kedua kelas homogen)

$\mathrm{H}_{1}: \sigma_{1}^{2} \neq \sigma_{2}^{2}$ (terdapat perbedaan varians penalaran matematis antara kelas eksperimen dan kelas kontrol yang berarti kedua kelas tidak homogen)

Dengan Levene's Test for Equality of Variances diperoleh $\mathrm{F}=0,352$ dan sig $=0,556$ $=55,60 \%>5 \%$ maka $\mathrm{H}_{0}$ diterima, ini berarti bahwa kedua sampel mempunyai varian yang sama. Selanjutnya dipilih Equal variance assumed, dengan hipotesis sebagai berikut.

$\mathrm{H}_{0}: \mu_{1}=\mu_{2}$ (tidak ada perbedaan nilai rata-rata penalaran matematis antara kelas eksperimen dengan kelas kontrol)

$\mathrm{H}_{1}: \mu_{1} \neq \mu_{2}$ (ada perbedaan nilai rata-rata penalaran matematis antara kelas eksperimen dengan kelas kontrol)

Hasil $t$-test for Equality of Means diperoleh sig $=0,000<5 \%$ sehingga $\mathrm{H}_{\mathrm{o}}$ ditolak, maka $\mu_{1} \neq \mu_{2}$ ini berarti terdapat perbedaan nilai rata-rata penalaran matematis antara kelas eksperimen dengan kelas kontrol. Besarnya perbedaan tersebut dapat dilihat pada Tabel 3.6 sebagai berikut.

Tabel 3.6

Rata-rata nilai TPM Kelas Eksperimen dan Kelas kontrol

\begin{tabular}{|ll|c|c|c|c|}
\hline & Kelas & $\mathrm{N}$ & Mean & Std. Deviation & Std. Error Mean \\
\hline TPM & Eksperimen & 21 & 73.33 & 15.032 & 3.280 \\
& Kontrol & 21 & 40.38 & 17.160 & 3.745 \\
\hline
\end{tabular}

Dari Tabel di atas dapat dilihat bahwa nilai rata-rata penalaran matematis kelas eksperimen yaitu 73,33 lebih besar dari nilai rata-rata penalaran matematis kelas kontrol yaitu 40,38. Ini berarti rata-rata nilai penalaran matematis kelas eksperimen lebih baik dari kelas kontrol. 


\section{Pembahasan}

Data hasil penelitian digunakan untuk mengetahui efektivitas penggunaan pendekatan metakognisi terhadap penalaran matematis. Efektifitas pendekatan metakognisi keberhasilan diukur melalui tiga uji statistika, yaitu 1) Uji ketuntasan penalaran matematis, 2) Uji pengaruh, dan 3) Uji banding (uji perbedaan). Hasil ketiga uji tersebut dapat dijelaskan sebagai berikut.

Telah dihasilkan dari uji ketuntasan klasikal bahwa penalaran matematis mahasiswa kelas eksperimen mencapai tuntas. Hal ini menunjukkan secara nyata keberhasilan proses pembelajaran menggunakan pendekatan metakognisi. Keberhasilan ini disebabkan karena pendekatan metakognisi berhasil meningkatkan kemampuan dan kecakapan yang dimiliki mahasiswa kearah positif terutama dalam kemampuan membantu teman dan memperhatikan kesulitan orang lain serta merencanakan bagaimana belajar. Mengetahui apa yang belum dan yang sudah mahasiswa ketahui, serta belajar dari kesalahan dari soal-soal penalaran matematis yang disajikan dalam bentuk metakognisi. Pada proses pembelajaran, mahasiswa akan menyadari pengetahuan yang sudah dan belum dimiliki mahasiswa. Sehingga mahasiswa dapat berpikir bagaimana cara berpikir untuk menambah pengetahuan mereka, dapat dengan cara merencanakan cara belajar, mengatur waktu belajar, dan mengumpulkan sumber-sumber belajar. Mahasiswa juga diberi soal-soal penalaran matematis dengan penyajian metakognisi. Soal berbentuk analisis jawaban, penyajian sejumlah soal beserta pembuktiannya akan menyadarkan mahasiswa terhadap apa yang sudah diketahuinya. John Dewey (Uno dan Mohamad: 2011: 196) mengemukakan bahwa belajar adalah menyangkut apa yang harus dikerjakan untuk diri sendiri, dengan demikian inisiatif harus datang dari siswa itu sendiri, artinya peran dosen sebagai pembimbing dan pengarah.

Penalaran matematis pada matakuliah geometri transformasi sangatlah penting diperlukan agar dapat mengembangkan cara berpikir matematis mahasiswa. Sternberg (English, 2004: 13) menyatakan bahwa penalaran matematis merupakan keterampilan yang superior dalam komputasi dan analisis untuk mengakomodasi proses yang penting dalam era berbasis pengetahuan saat ini. Beberapa indikator penalaran matematis antara lain mengumpulkan bukti, menganalisis data, membuat dugaan (konjektur), membangun argumen, menggambar dan memvalidasi kesimpulan logis dan membuktikan pernyataan. Semua indikator tersebut merupakan tujuan dari pembelajaran matakuliah geometri transformasi.

Hasil perhitungan yang dilakukan diperoleh $\mathrm{R}$ square sebesar 39,60\% dan persamaan estimasi regresi $\hat{Y}=36,792+0,591 X$. Variabel X menyatakan aktivitas

belajar dan variabel $Y$ menyatakan penalaran matematis mahasiswa. Hal ini menunjukkan bahwa penalaran matematis juga dipengaruhi oleh aktivitas belajar. Hasil penelitian ini relevan dengan penelitian Noto, dkk (2014: 39), yang 
menyatakan bahwa terdapat pengaruh aktivitas mahasiswa dalam pendekatan metakognisi terhadap penalaran matematis. Perbedaannya, penelitian tersebut dilakukan pada matakuliah statistika matematika.

Uno dan Mohamad (2011: 191) mengemukakan bahwa aktivitas merupakan salah satu prinsip dasar pada pembelajaran yang efektif, belajar hanya memungkinkan terjadi apabila peserta didik aktif dan mengalaminya sendiri. Dalam penelitian ini pengaruh aktivitas mahasiswa terhadap penalaran matematis sebesar 39,60\%. Dan sisanya $61,40 \%$ dipengaruhi oleh faktor lain yang mempengaruhi. Slameto (2003: 54) menyatakan bahwa faktor-faktor yang mempengaruhi belajar adalah faktor intern dan faktor ekstern.

Faktor intern meliputi faktor jasmaniah, psikologi dan faktor kelelahan diantaranya seperti minat belajar, tingkat intelegensi, persepsi mahasiswa terhadap dosen ataupun motivasi mahasiswa. Menurut Noto (2014a: 9), motivasi juga mempengaruhi kemampuan penalaran matematis mahasiswa. Sedangkan faktor ekstern seperti keadaan sosial, iklim sosial dalam kelas, karakteristik belajar. Persamaan regresi yang diperoleh juga menunjukkan bahwa rata-rata skor penalaran matematis bertambah sebesar 0,591 untuk penambahan satu skor aktivitas mahasiswa dalam pendekatan metakognisi.

Nilai rata-rata kemampuan penalaran matematis mahasiswa pada kelas yang menggunakan pendekatan metakognisi lebih besar dibandingkan nilai rata-rata kemampuan penalaran matematis pada kelas kontrol. Terdapat perbedaan yang signifikan penalaran matematis mahasiswa antara pembelajaran dengan menggunakan pendekatan metakognisi dengan pembelajaran ekspositori. Hasil ini sejalan dengan pendapat Noto, dkk (2014b: 38) bahwa pembelajaran dengan pendekatan metakognisi yang lebih menekankan pada aktivitas dan mengembangkan kemampuan mahasiswa untuk merencanakan bagaimana harus belajar dan berpikir bagaimana cara berpikir lebih baik dari pembelajaran ekspositori.

\section{KESIMPULAN}

Pembelajaran dengan pendekatan metakognisi efektif terhadap penalaran matematis mahasiswa, beberapa indikator terpenuhi, yaitu (1) Nilai rata-rata penalaran matematis mahasiswa mencapai ketuntasan klasikal yaitu 73.33 lebih besar dari KKM (65), (2) Aktivitas mahasiswa pada pembelajaran dengan pendekatan metakognisi berpengaruh positif terhadap penalaran matematis mahasiswa dalam kegiatan belajar, aktivitas mahasiswa berpengaruh terhadap penalaran matematis mahasiswa sebesar 39,60\%, (3) Nilai rata-rata penalaran matematis mahasiswa pada pembelajaran dengan pendekatan metakognisi (rata-rata 73.33) lebih baik daripada kelas kontrol (rata-rata 40,38). 


\section{DAFTAR PUSTAKA}

English, L. D. (2004). Mathematical and Analogical Reasoning of Young Learners. New Jersey: Lawrence Erlbaum Associates Publishers.

Hamalik, O. (2008). Proses Belajar Mengajar. Jakarta: PT. Bumi Aksara.

Hvidsten, M. (2005). Geometry with Geometry Explorer TM. New York: McGrawHill Education (Asia).

Kuntjojo (2009). "Metakognisi dan Keberhasian Belajar Peserta Didik" http://ebekunt.wordpress.com/2009/04/12/metakognisi-dan-keberhasilanbelajar-peserta-didik/. Diakses pada 14 Agustus 2009.

Noto, M. S., Rosita, C. D., Laelasari (2014a). Pengaruh Motivasi dan Aktivitas dalam Pendekatan Pembelajaran Konstruktivisme terhadap Kemampuan Pemahaman dan Penalaran Matematis pada Mata Kuliah Aljabar Linear 1. Prosiding Seminar Nasional Pendidikan Matematika Ahmad Dahlan 2014. Yogyakarta: UAD.

Noto, M.S dkk. (2014b). Pendekatan Metakognisi Untuk Meningkatkan Kemampuan Penalaran Matematis Mahasiswa Semester IV Mata Kuliah Statistika Matematika. Jurnal Delta Vol. 2 No. 1. Pekalongan: UNIKAL.

Muisman (2002). "Metakognisi", Bab II Kajian Pustaka, 24-26. http://www. demandiri.or.id/file/muisman. Diakses pada 10 Agustus 2009.

Ruseffendi, E. T. (2010). Dasar-Dasar Penelitian Pendidikan dan Bidang NonEksakta Lainnya. Bandung: Tarsito.

Slameto (2003). Belajar dan Faktor-Faktor yang Mempengaruhinya. Jakarta: Rineka Cipta.

Sugiono (2009). Metode Penelitian Pendidikan: Pendekatan Kuantitatif, Kualitatif dan $R \& D$. Bandung: alfabeta

Sukestiyarno (2010). Olah Data Penelitian Berbantuan SPSS. Semarang: Universitas Negeri Semarang Press

Uno, H. B. (2009). Model Pembelajaran Menciptakan Proses Belajar Mengajar yang Kreatif dan Efektif. Jakarta: PT Bumi Aksara.

Uno, H. B dan Mohamad, N. (2011). Belajar dengan Pendekatan PAIKEM. Jakarta: Bumi Aksara. 